\title{
Rancang Bangun Alat Ukur Getaran Mesin Sepeda Motor Menggunakan Sensor Serat Optik
}

\author{
Nadia Yudia Putri*, Harmadi, Wildian \\ Laboratorium Elektronika dan Instrumentasi, JurusanFisika FMIPAUniversitasAndalas \\ Kampus Unand, Limau Manis, Padang, 25163 \\ *nadia.yudia@yahoo.com
}

\begin{abstract}
ABSTRAK
Telah dirancang alat ukur getaran mesin sepeda motor menggunakan sensor serat optik dengan metode ekstrinsik. Sensor serat optik digunakan untuk mengukur frekuensi getaran dengan memanfaatkan perubahan tegangan keluaran fotodioda OPT101. Sumber getaran berasal dari mesin sepeda motor yang divariasikan kecepatan speedometernya. Sistem pengukuran getaran mesin sepeda motor ini terdiri dari sumber cahaya berupa laser dioda, serat optik FD-620-10, fotodioda OPT 101, mikrokontroler Arduino Uno sebagai pemroses sinyal, dan LCD sebagai penampil hasil pengukuran. Berdasarkan data pengujian dan analisis yang telah dilakukan, diperoleh kesimpulan bahwa alat ukur getaran mesin sepeda motor memiliki keakuratan $90 \%$ dengan variasi kelajuan speedometer $0 \mathrm{~km} / \mathrm{jam}-20 \mathrm{~km} / \mathrm{jam}$.

Kata Kunci: frekuensi, getaran, laser dioda, serat optik
\end{abstract}

\section{ABSTRACT}

The vibration of motorcycle machine measurement instrument using extrinsic method of optical fiber sensor has been designed. Optical fiber sensors was used to measure the frequency of vibration by used the alteration output of photodiode OPT101. The vibration source was a machine of the motorcycle with speed variation. The system consist of diode laser, optical fiber FD-620-10, OPT photodiode 101, Arduino Uno microcontroller as signal processing, and the LCD as an output display of measurement value. Based on data value and data analyze that have been done. It concluded that the frequency of vibration measurement system have the accuration of $90 \%$ with speed variety of motorcycle machine is 0 $\mathrm{km} / \mathrm{hour}-20 \mathrm{~km} / \mathrm{hour}$.

Keywords: diode laser, fiber optics, frequency, vibration

\section{PENDAHULUAN}

Fenomena getaran banyak ditemukan dalam kehidupan sehari-hari. Getaran adalah gerakan bolak balik dalam suatu interval waktu tertentu. Getaran berhubungan dengan gerak osilasi benda dan gaya yang berhubungan dengan gerak tersebut. Getaran yang sering kita rasakan berasal dari mesin-mesin yang kita gunakan. Mesin-mesin tersebut menghasilkan getaran dengan karakteristik yang berbeda-beda.Salah satu mesin yang menimbulkan getaran dan sering digunakan masyarakat Indonesia adalah sepeda motor.

Getaran mesin dari dalam disebabkan oleh komponen mesin yang mempunyai sifat bahan elastis, ketika komponen (part) mesin bergerak secara berputar (rotasi) atau translasidapat menimbulkan getaran (Sunarko, 2010). Analisis getaran dapat dilakukan untuk mengetahui kondisi kerusakan mesin. Kerusakan kecil yang biasa terjadi pada mesin sepeda motor adalah klep yang tidak standar, karburator kotor mengakibatkan suplai campuran bahan bakar dan udara ke ruang bakar menjadi kotor atau pembakaran tidak sempurna, pelumasan oli tidak baik sehingga proses pendinginan ke mesin tidak sempurna atau karena banyaknya pemalsuan oli di pasaran, dan lain-lain.

Beberapa penelitian yang terkait telah dilakukan Sunarko (2010) mengubah pengukuran sinyal getaran dari domain waktu ke domain frekuensi dengan menggunakan analisis fast fourier transform (FFT) dari sensor accelerometer. Risa (2016) mengubah pengukuran sinyal getaran dari domain waktu ke domain frekuensi dengan menggunakan analisis FTT dan menggunakan metode Predictive Maintenance serta tambahan fitur aplikasi mobile yang bisa dibawa kemana-mana.Penelitian yang telah dilakukan menggunakan prinsip kontak langsung dimana objek yang diukur kontak langsung dengan instrumen yang digunakan. Pengukuran frekuensi getaran menggunakan serat optik telah banyak dilakukan oleh beberapa peneliti, diantaranya Spillman dkk (1998) dengan melakukan penginderaan getaran menggunakan deteksi perubahan dalam distribusi spasial energi dalam output dari serat optik multimode. 
Zulaichah (2004) memanfaatkan serat optik sebagai sensor yang mengubah besaran fisik getaran yaitu simpangan menjadi besaran tegangan

Jika objek yang akan diukur berada pada suhu yang tinggi atau terlalu rendah maka instrumen yang digunakan bisa rusak. Sensor yang digunakan juga sangat sensitif pada suhu yang tinggi dan kemungkinan bisa rusak. Dalam penelitian ini digunakan sensor serat optik dengan metode non kontak sehingga instrumen yang digunakan lebih tahan lama ketika melakukan pengukuran.

\section{METODE}

Alat ukur getaran mesin sepeda motor menggunakan sensor serat optik ini terdiri dari 2 bagian utama yaitu perangkat keras (hardware) dan perangkat lunak (software). Sistem perangkat keras ini terdiri dari serat optik FD-620-10 tipe step-index multimode, arduino Uno R3, Laser Dioda, pengkondisi sinyal, dan catu daya yang terlihat pada Gambar 1.

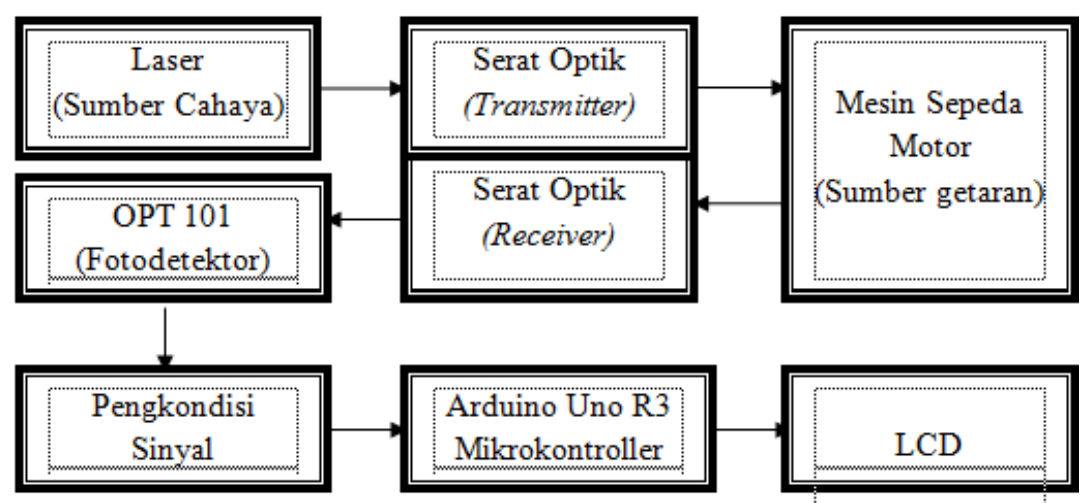

Gambar 1 Diagram blok system alat ukur getaran mesin sepeda motor menggunakan sensor serat optik

Sistem sensor serat optik pada penelitian ini dirancang menggunakan metode ekstrinsik dimana proses pengindraan terhadap suatu objek terjadi di luar serat optik tersebut tanpa dilakukan modifikasi. Cahaya dari laser akan ditransmisikan melalui transmitter serat optik sehingga ketika mesin sepeda motor bergetar cahaya tersebut terpantulkan dan dideteksi oleh sensor fotodetektor OPT101. Tegangan keluaran dari OPT101 diproses oleh arduino Uno menjadi frekuensi. Penampil data hasil pengukuran menggunakan sambungan USB dari sistem sensor menuju LCD.

\subsection{Perancangan Perangkat Lunak Sistem Sensor}

Sistem perancangan perangkat lunak ini bertujuan untuk memproses sinyal masukan dari sensor serat optik ini. Desainnya berupa source code atau disebut juga program. Program ditanamkan dalam mikrokontroller pada arduino UNO R3 menggunakan bahasa C. Arduino Uno akan mencacah jumlah sinyal masukan digital tiap satu detik menggunakan library frequency counter. Hasil proses pencacahan tersebut merupakan nilai dari frekuensi mesin sepeda motor yang diindra oleh sensor serat optik. Nilai frekuensi yang terukur akan dikirim ke LCD dan ditampilkan secara real time pada layar LCD. Diagram alir proses pengukuran frekuensi getaran dapat dilihat pada Gambar 2. 


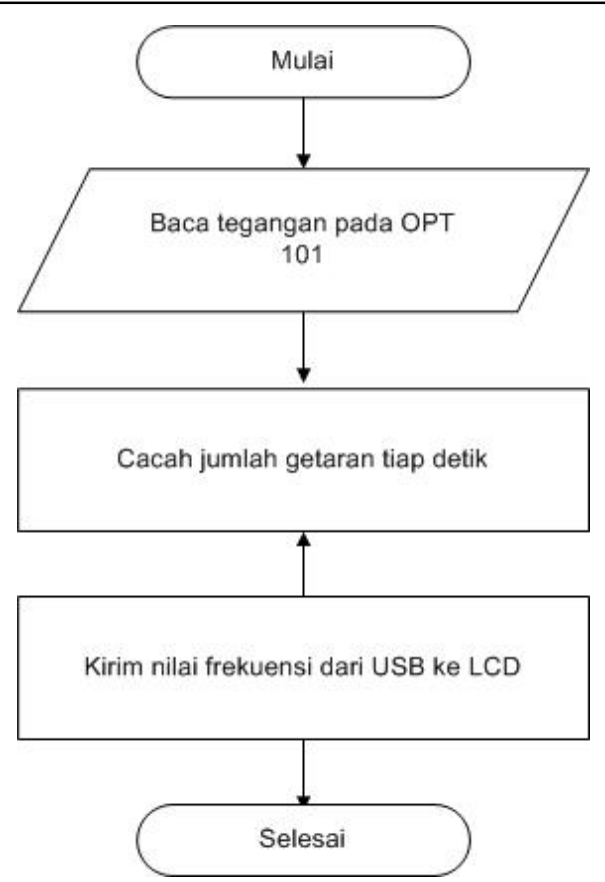

Gambar 2 Diagram alir pengukuran frekuensi getaran.

\subsection{Perancangan Rangkaian Fotodetektor}

Pengukuran getaran dengan sensor serat optik menggunakan fotodetektor OPT101 untuk mendeteksi intesitas cahaya yang dipandu oleh serat optik receiver. Fotodetektor OPT101 memerlukan komponen tambahan untuk dapat mengubah intensitas cahaya menjadi tegangan keluaran. Gambar 3 memperlihatan skema rangkaian dari fotodetektor OPT101 dengan komponen tambahan yang digunakan adalah kapasitor bernilai $0,1 \mu \mathrm{F}$ dan $100 \mu \mathrm{F}$ yang dirangkai secara paralel serta resistor $100 \Omega$.

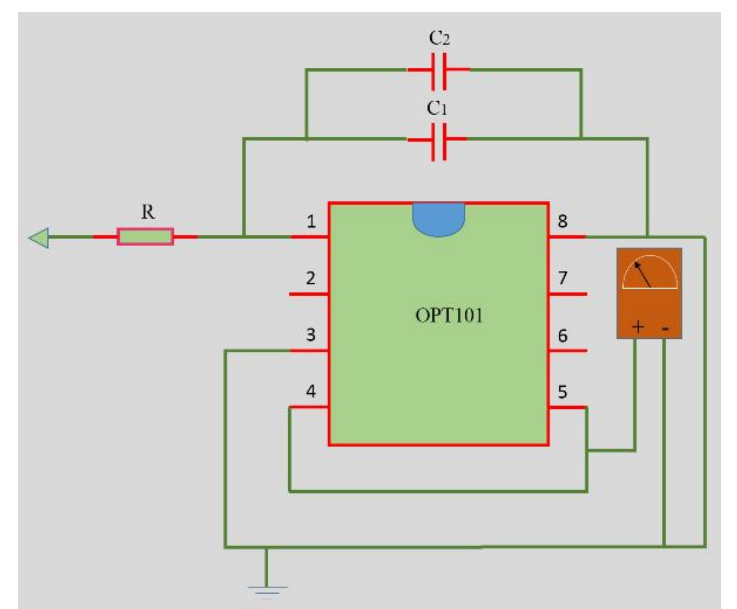

Gambar 3 Skematik rangkaian fotodetektor OPT101

\subsection{Karakterisisasi Sensor Serat Optik}

Karakterisasi sistem sensor serat optik dilakukan dengan memvariasikan jarak antara serat optik dengan mesin sepeda motor. Tegangan keluaran fotodetektor diukur menggunakan multimeter. Variasi jarak yang diberikan berkisar antara $0 \mathrm{~mm}$ hingga $15 \mathrm{~mm}$ dengan beda sebesar $1 \mathrm{~mm}$. Gambar 4 memperlihatkan skema karakterisasi sensor serat optik untuk mendapatkan jarak yang paling optimal. Perubahan jarak akan menyebabkan tegangan keluaran yang juga bervariasi pada fotodetektor. Hal ini disebakan oleh banyak atau sedikitnya intensitas cahaya yang diterima oleh fotodetektor 101. Hasil karakterisasi akan menentukan jarak paling sensitif untuk melakukan pengukuran frekuensi getaran. 


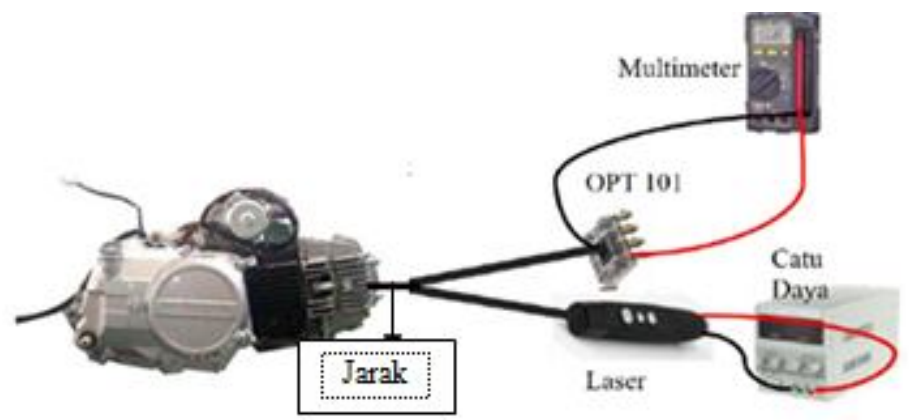

Gambar 4 Skematik karakterisasi sensor

\subsection{Pengujian Sistem Pengukuran dan Pengumpulan Data}

Pengujian sistem pengukuran ini dilakukan dengan cara membandingkan hasil pengukuran pada alat ukur dengan alat ukur standar getaran yang menggunakan sensor accelerometer. Alat ukur diuji menggunakan mesin sepeda motor yang divariasikan kelajuan yang terbaca pada speedometer dan diukur frekuensi yang dihasilkan oleh motor tersebut. Frekuensi yang didapatkan dibandingkan dengan alat ukur yang menggunakan sensor accelerometer untuk melihat keakuratan sistem yang telah dirancang. Motor yang diuji dalam kondisi baru diservis dan kondisi yang belum diservis.

\subsection{Teknik Analisis Data}

Analisis data merupakan proses untuk mengetahui tingkat ketepatan dan ketelitian dari suau sistem pengukuran. Ketepatan (akurasi) merupakan tingkat kesesuaian atau dekatnya suatu hasil pengukuran terhadap nilai sebenarnya. Ketepatan dari sistem dapat ditentukan dari persentase kesalahan antara nilai aktual dengan nilai terlihat. Besar persentase kesalahan pada pengujian skala suatu alat ukur dapat ditentukan dengan Persamaan 1.

$$
\text { Persentase kesalahan }=\left|\frac{Y_{n}-X_{n}}{Y_{n}}\right| \times 100 \%
$$

Yn adalah nilai sebenarnya dan Xn adalah nilai yang terbaca pada alat ukur.

\section{HASIL DAN DISKUSI}

Pengujian alat ukur getaran mesin sepeda motor menggunakan sensor serat optik telah dilakukan. Pengujian dilakukan baik terhadap perangkat keras maupun perangkat lunak. Tujuan dari pengujian untuk mengetahui apakah sistem yang dirancang dapat bekerja dan berfungsi dengan baik. Bentuk fisik sensor getaran secara keseluruhan dapat dilihat pada Gambar 6.

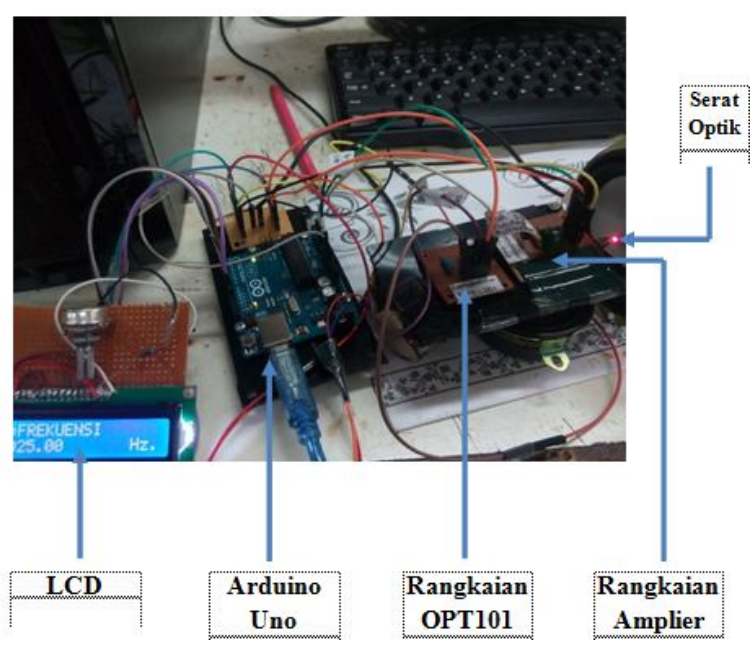

Gambar 5 Bentuk fisik sensor getaran 


\subsection{Hasil Karakteristik Sensor Serat Optik}

Karakterisasi dilakukan dengan cara memvariasikan jarak antara mesin sepeda motor dengan ujung dari serat optik. Hal ini akan menyebabkan tegangan keluaran pada fotodioda OPT101 yang terbaca pada multimeter akan berbeda-beda tergantung pada jaraknya. Jarak sensor serat optik dengan mesin sepeda motor dimulai dari $0 \mathrm{~mm}-10 \mathrm{~mm}$ dengan beda $1 \mathrm{~mm}$. Kemudian diplot tegangan keluaran rata-rata terhadap jarak seperti Gambar 7. Pada grafik dapat dilihat bahwa pada jarak $0 \mathrm{~mm}-1 \mathrm{~mm}$ tegangan naik, kemudian tegangan semakin menurun menuju angka yang seiring bertambah jauhnya jarak sensor serat optik terhadap mesin sepeda motor. Puncak tertinggi tegangan dilihat pada grafik yaitu pada jarak $1 \mathrm{~mm}$ dengan tegangan keluaran $0,17 \mathrm{~V}$. Hasil ini digunakan untuk menentukan jarak paling optimal untuk pengukuran yaitu $1 \mathrm{~mm}$.

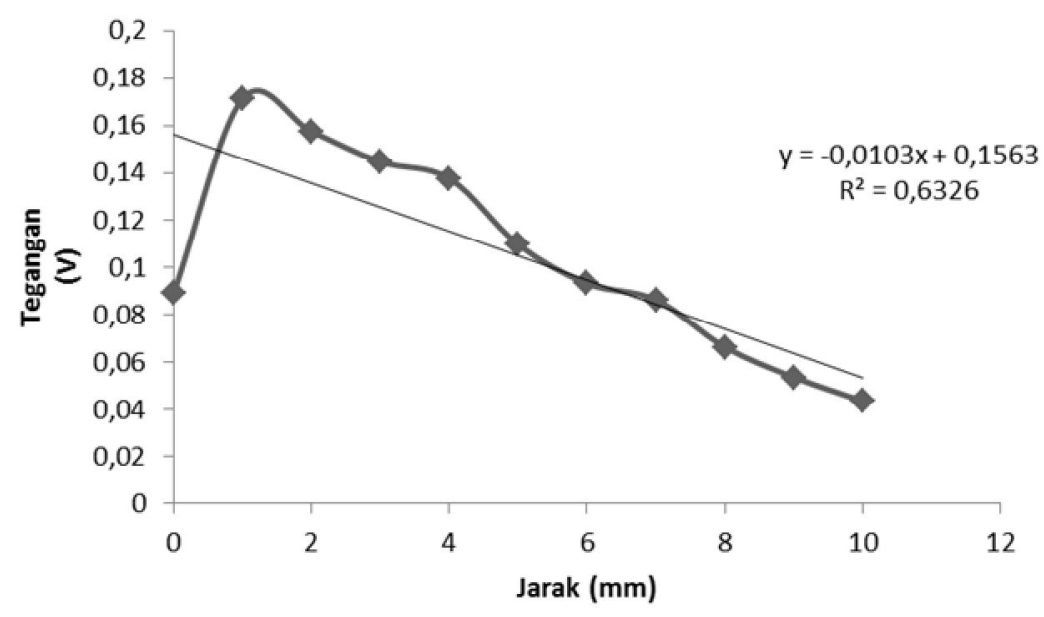

Gambar 6 Grafik perubahan tegangan keluaran fotodioda OPT101antara mesin sepeda motor dan serat optik terhadap jarak.

\subsection{Hasil Pengujian Sistem Pengukuran}

Grafik hasil pengukuran frekuensi getaran mesin terhadap kelajuan dapat dilihat pada Gambar 8. Hasil yang didapatkan dibandingkan dengan alat ukur getaran yang menggunakan sensor accelerometer. Frekuensi yang terukur menggunakan sensor accelerometer dan menggunakan sensor serat optik tidak jauh berbeda. Pada Gambar 8 dapat dilihat frekuensi getaran pada motor yang kurang baik memiliki nilai yang lebih tinggi jika dibandingkan dengan motor yang baik. Frekuensi getaran dari mesin sepeda motor meningkat seiring menurunnya kondisi dari mesin tersebut, hal ini disebabkan karna semakin parah kerusakan yang dialami mesin sepada motor maka semakin besar pula frekuensi yang dihasilkan oleh mesin tersebut. Mesin sepeda motor yang mengalami kerusakan memiliki amplitudo getaran yang lebih besar dibandingkan dengan mesin sepeda motor yang lebih baik. Semakin tinggi kelajuan mesin sepeda motor maka frekuensi getarannya juga semakin besar. Hasil pengukuran yang telah didapatkan dilakukan perhitungan dengan keakuratan alat ukur $90 \%$. 


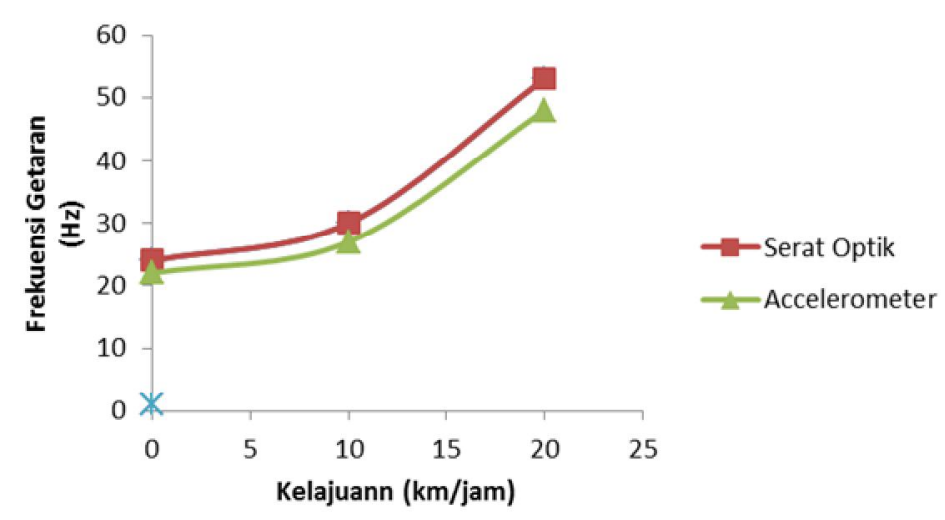

(a)

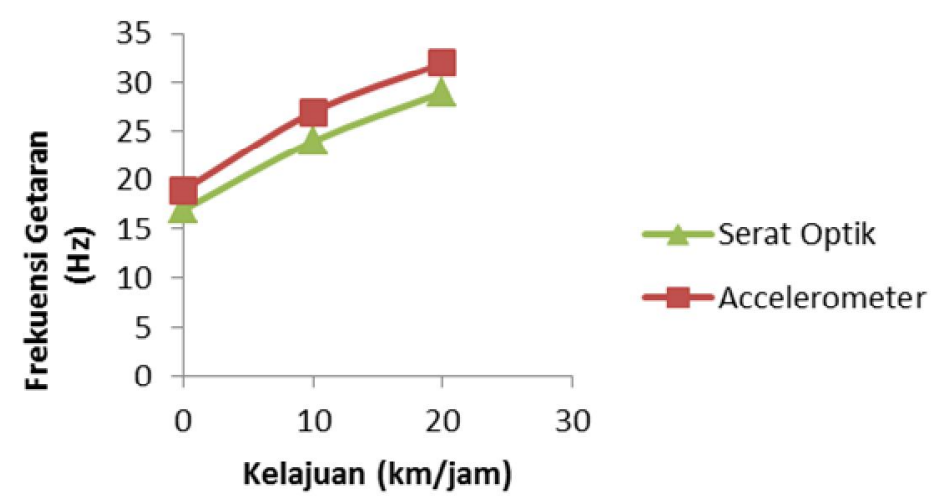

(b)

Gambar 7 Grafik hasil pengukuran frekuensi getaran mesin terhadap kelajuan yang terbaca pada speedometer (a) untuk mesin motor yang kurang baik,

(b) untuk mesin motor yang baik.

Grafik tegangan keluaran fotodioda OPT101 terhadap mesin sepeda motor dapat dilihat pada Gambar 9. Tegangan keluaran OPT101 semakin besar seiring bertambahnya kelajuan yang terbaca pada speedometer. Getaran dari mesin sepeda motor yang semakin besar menandakan bahwa amplitudo getarannya juga besar. Intensitas cahaya yang diterima oleh fotodetektor OPT101 juga semakin besar dan tegangan keluaran dari fotodetektor OPT101 juga besar. Sebaliknya jika amplitudo getaran kecil maka intensitas cahaya yang diterima oleh fotodetektor OPT101 juga semakin kecil sehingga tegangan keluarannya menjadi kecil.

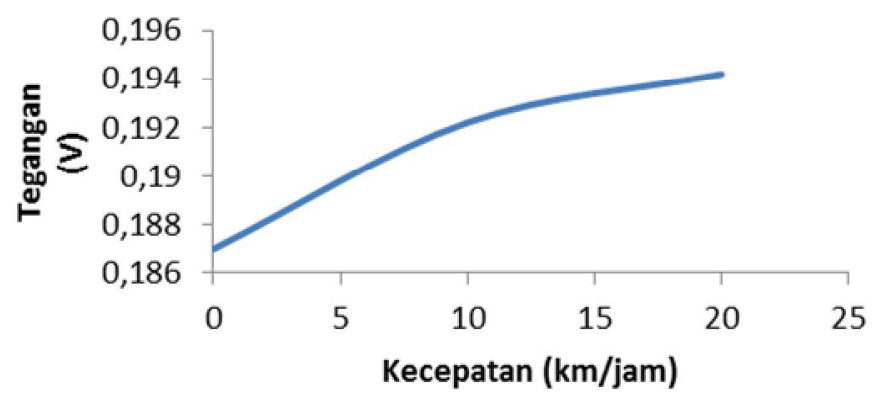

(a) 


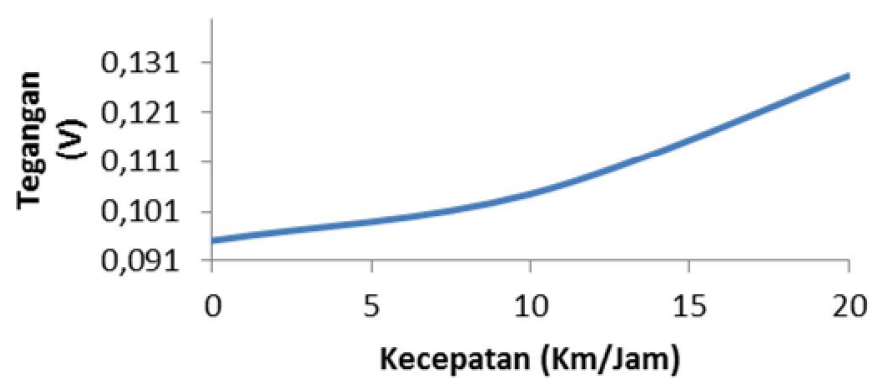

(b)

Gambar 8 Grafik tegangan keluaran fotodetektor OPT101 (a) motor kurang baik, (b) motor baik

\section{KESIMPULAN}

Alat ukur getaran mesin sepeda motor menggunakan sensor serat optik yang telah dirancang memiliki persentase error rata-rata 10\%.Fungsi transfer sistem sensor serat optik pada alat ukur getaran mesin sepeda motor ini adalah $y=-0,002 x+0,96$. Pengukuran getaran dengan menggunakan sensor serat optik paling efektif pada jarak $1 \mathrm{~mm}$. Hasil pengukuran frekuensi dapat dilakukan secara real time dengan tampilan langsung pada LCD. Mesin sepeda motor yang kurang baik memiliki frekuensi getaran yang tinggi dibandingkan dengan mesin sepeda motor yang baik. Pengukuran dengan menggunakan sensor serat optik ini bisa mengukur dalam jangka waktu yang lebih lama daripada menggunakan sensor accelerometer yang tidak tahan terhadap panas dari mesin sepeda motor.

\section{DAFTAR PUSTAKA}

Risa, A.R., 2016, Sistem Identifikasi Kondisi Sepeda Motor dengan Algoritma Fast Fourier Transform serta Bantuan Android dan Google Maps. Universitas Andalas, Padang.

Spillman, W.B., Kline B.R., Maurice L.B., Fuhr P.L., 1989, Statistical-mode sensor for fiber optic vibration sensing uses. OSA Publishing, Vol.28, America.

Sunarko, B.K., 2010, Analisa Getaran Pada Mesin Sepeda Motor Berbasi Labview, Tesis, Universitas Indonesia, Jakarta.

Zulaichah, S., 2004, Pengukuran Frekuensi Getaran Menggunakan Serat Optik, Skripsi, ITB, Bandung. 